\title{
Pengaruh Informasi Asimetrik Terhadap Masalah Agency Kontraktual Dalam Pembiayaan Mudharabah
}

\author{
Nurfauziah* \\ Nur Syakdiyyah**
}

\section{Abstract}

This study analyzed the influence of Asymmetric Infornation of the Contractual Agency Problems in Mudharabah. Asymmetric information in this study was based on the form of adverse selection and moral hazard. Moral hazard is an aberration that cannot be observed by Shahibul Maal. Negative actions or activities.of the entrepreneur (mudharib) are not known by Shahibul Maal so that mudharib can freely act without the knowledge of them. Adverse selection associated with the ethics of a mudharib inherently and cannot be known certainly by Shahibul Maal.

The research was conducted on Sharia Commercial Banks in DIY and Central Java, namely BTN Syariah, Bank Syariah Mandiri, BRI Syariah. Through regression analysis, it showed that Moral Hazard and Adverse Selection effected on the contractual agency problems both individually and simultanously.

Keywords: Asymmetric Information, Mudharabah, Contractual Agency Problems

\section{Pendahuluan}

Bank Syari'ah dalam menjalankan operasionalnya berdasarkan prinsip yang sudah ditentukan secara syari'ah Islam, yaitu keuntungan diperoleh berdasarkan prinsip bagi hasil. Prinsip bagi hasil yang biasa digunakan ada dua macam kontrak yaitu mudharabah (trustee profit sharing) dan musyarakah (profit joint venture).

Mudharabah (trustee profit sharing) adalah perjanjian usaha antara penyedia dana (shahibul maal) dengan entrepreneur (mudharib) dimana dana tersebut digunakan untuk melakukan pengelolaan suatu usaha. Sedangkan musyarakah (profit joint venture) adalah kerjasama antara dua pihak atau lebih untuk suatu

- Dosen Fakultas Ekonomi UII

* Alumni Fakultas Ekonomi UII 
usaha tertentu dimana masing-masing pihak memberikan kontribusi dana dengan kesepakatan bahwa keuntungan dan risiko akan ditanggung bersama sesuai dengan kesepakatan, (Antonio,2001).

Dalam pembiayaan Mudharabah hampir dipastikan akan terjadi hubungan kontrak keuangan yang lebih dikenal dengan hubungan agency (agency contractual). Agency contractual terjadi ketika ada benturan kepentingan antara mudharib dan shahibul maal. Mudharib cenderung mengabaikan hubungan kontraktual dan bertindak tidak berdasarkan kepentingan shahibul maal atau bertindak tidak sesuai dengan kesepakatan sebelumnya.

Shahibul maal tidak diperbolehkan ikut campur dalam pengelolaan usaha yang sedang ditangani oleh mudharib. Kesempatan itulah yang memicu mudharib untuk bertindak tidak transparan dalam memberikan informasi tentang keadaan bisnis yang sebenarnya kepada shahibul maal untuk kepentingan pribadinya. Mudharib memiliki informasi yang lebih dibandingkan shahibul maal. Shahibul maal tidak memperoleh informasi lain selain informasi yang diberikan oleh mudharib. Sehingga ada celah bagi mudharib untuk berbuat tidak sesuai dengan kesepakatan dan perjanjian sebelumnya dengan tidak memberikan informasi yang semestinya kepada pihak shahibul maal. Dari ketimpangan informasi (informasi asimetrik) itulah yang menimbulkan adanya masalah agensi dalam suatu kontrak.

Informasi asimetrik dapat berbentuk moral hazard dan adverse selection. Moral hazard merupakan suatu penyimpangan yang tidak dapat diamati oleh shahibul maal. Tindakan negative atau aktivitas dari mudharib tidak diketahui oleh shahibul maal sehingga mudharib dapat dengan leluasa bertindak tanpa sepengetahuan shahibul maal ketika melakukan penyimpangan dan menimbulkan suatu resiko yang besar karena tidak dapat diamati oleh shahibul maal. Adverse selection berkaitan dengan etika seorang mudharib yang melekat pada dirinya dan tidak dapat diketahui secara pasti oleh shahibulmaal. Kemungkinan penyimpangan yang terjadi dapat berupa terjadinya kecurangan atau penyimpangan terhadap pembagian hasil usaha diantara keduanya atau saling mencoba memanfaatkan pihak lain untuk kepentingan sendiri

Variabel-variabel mengenai masalah agency kontraktual dan informasi asimetrik ini sangat menarik untuk diteliti terutama dalam pembiayaan mudharabah karena kontrak mudharabah sering berhubungan dengan masalah keuangan dan hubungan keagenan. Selain itu variabel informasi asimetrik ini jarang diukur secara khusus dalam penelitian-penelitian sebelumnya.

Berdasarkan uraian diatas, dipandang perlu dilakukan penelitian tentang Pengaruh Informasi Asimetrik terhadap Masalah Agency Contractual dalam Pembiayaan Mudharabah. Tujuan penelitian ini untuk mengetahui pengaruh moral hazard dan adverse selection terhadap agency contractual. 


\section{Kajian Pustaka}

\section{Pembiayaan Mudharabah}

Mudharabah adalah suatu perjanjian usaha antara pihak pertama (penyedia dana) dengan pihak kedua (pengelola). Disini yang menjadi pihak pertama adalah penyedia dana (shahibul maal) yang menyediakan dana guna membangun suatu usaha. Sedangkan pihak kedua adalah pengelola (mudharib) yang mengelola usaha yang telah ditentukan. Apabila mendapat keuntungan, akan dibagi sesuai dengan perjanjian sebelumnya. Jika usaha tersebut mengalami kerugian, kerugian tersebut ditanggung oleh shahibul maal. Namun jika kerugian tersebut dikarenakan oleh kecurangan atau kelalaian mudharib, maka mudharib juga ikut bertanggungJawab atas kerugian tersebut sesuai dengan perjanjian sebelumnya. Kontrak mudharabah dapat diberhentikan kapan saja oleh salah satu pihak dengan syarat ada konfirmasi terlebih dahulu kepada pihak lainnya.

Kerjasama yang dilakukan oleh shahibul maal dengan mudharib dalam kontrak mudharabah ini harus berjalan sesuai rukun mudharabah sebagai prasyarat sahnya transaksi. Mudharabah merupakan alternatif dalam penerapan prinsip bagi hasil dan diperkuat dengan landasan dasar syari'at Islam yang mendukung keberadaan produk syari'ah ini.

\section{Rukun Mudharabah}

Dalam pembiayaan mudharabah ada rukun yang harus dilakukan sebagai prasyarat akan sahnya suatu pembiayaan (Muhamaad, 2003) antara lain :

1. Adanya pelaku akad, baik shahibul maal maupun mudharib

2. Objek akad berupa harta atau modal usaha

3. Adanya usaha yang dikelola oleh mudharib

4. Keuntungan yang akan dibagi kepada kedua pihak

5. Sighah, atau ijab dan qabul

\section{Nisbah Bagi Hasil}

Pengalokasian kentungan dan kerugian dalam akad mudharabah ditentukan berdasarkan kesepakatan awal dalam kontrak antara kedua belah pihak. Bagi hasil ini harus ditentukan berdasarkan nilai kebebasan dan nilai keadilan. Berdasarkan aturan umum syari'ah, dalam pembiayaan mudharabah ini jika , usaha yang dibangun mengalami kerugian, seluruhnya menjadi tanggungJawab pemilik modal dengan syarat tidak ada kecurangan dan kelalaian dari si pengelola usaha.

\section{Masalah Agency Contractual dalam Pembiayaan Mudharabah}

Kontrak mudharabah jika dikaitkan dengan teori keuangan sering berhubungan dengan masalah agency (Muhammad, 2006). Masalah agency 
terjadi karena lemahnya control dari penyedia dana (sahibul maal). Selain itu mudharib bertindak mengabaikan hubungan kontraktual dengan shahibul maal dan mementingkan kepentingan pribadinya. Masalah agency ini sangat sering terjadi mengingat prosentase kepemilikan modal yang diberikan oleh shahibul maal lebih besar daripada mudharib. Masalah agency ini merupakan penyimpangan yang sering dilakukan oleh mudharib dan berkaitan dengan aspek standar moral dan tidak efektifnya model pembiayaan bagi hasil baik dalam aktifitas bisnis maupun dengan shahibul maal.

Dalam pembiayaan mudharabah, hubungan keagenan terjadi ketika shahibul maal memberikan wewenang kepada mudharib dalam mengelola suatu usaha yang sedang dimodali oleh shahibul maal dengan harapan usaha tersebut memberikan hasil atau keuntungan kepada shahibul maal. Mudharib yang dibiayai oleh shahibul maal harus memberi dan melakukan yang terbaik untuk shahibul maal demi kepentingan bersama. Namun sering kali hubungan keduanya terjadi konflik ketika dalam hubungan tersebut memiliki informasi asimetrik. Untuk itu harus ada screening untuk meminimalisir adanya informasi asimetrik (Arifin, 2007).

\section{Masalah Agency Contractual dan Informasi Asimetrik dalam Pembiayaan Mudharabah}

Dalam pembiayaan mudharabah, keuntungan bersih harus dibagi sesuai dengan kesepakatan sebelumnya antara shahibul maal dan mudharib. Seluruh pengeluaran rutin yang berkaitan dengan bisnis yang dibiayai secara mudharabah, dapat dimasukkan dalam beban operasional, bukan dinikmati untuk kepentingan mudharib melainkan untuk kepentingan bisnis yang sedang dirintis. Pembagian laba tidak akan dilakukan sebelum kerugian ditutup dan kewajiban terbayar kembali kepada shahibul maal, apabila pembagian keuntungan telah dibayar sebelum kewajiban terbayar kepada shahibul maal, maka akan dianggap sebagai pembagian keuntungan dimuka. Untuk itu harus ada keterbukaan informasi masalah keuangan dalam menjalankan bisnis yang dibiayai secara mudharabah karena berkaitan dengan penerimaan dan pengeluaran yang akan dibiayai oleh pihak bank.

Saat proses pertama bisnis berjalan mudharib menunjukan etikanya dengan baik dan bertindak sesuai dengan kesepakatan sebelumnya. Namun ketika bisnis tersebut sudah lama dijalankan, biasanya muncul tindakan yang tidak dapat dikendalikan. Tindakan itu berupa informasi asimetrik yang dilakukan oleh pihak mudharib terhadap shahibul maal atau pemberi modal. Hasil dari beberapa penelitian sebelumnya, menyatakan bahwa informasi asimetrik ini dapat mempengaruhi besar kecilnya pendapatan atau keuntungan dari suatu investasi. 


\section{Moral hazard}

Hazard adalah kondisi yang potensial menyebabkan terjadinya kerugian atau kerusakan (Muhammad, 2005). Moral hazard yaitu bahwa para manajer serta orang-orang dalam lainnya biasanya mengetahui lebih banyak tentang keadaan dan prospek perusahaan dibandingkan investor pihak luar (Scott, 2000). Tindakan negative atau aktivitas dari pengelola usaha tidak diketahui oleh penyedia dana sehingga pengelola dapat dengan leluasa bertindak tanpa sepengetahuan penyedia dana ketika melakukan penyimpangan dan menimbulkan suatu resiko yang besar karena tidak dapat diamati oleh penyedia dana. Moral hazard merupakan suatu penyimpangan yang tidak dapat diamati oleh shahibul maal.

\section{Adverse selection}

Adverse selection atau seleksi merugikan yaitu bahwa kegiatan yang dilakukan oleh seorang manajer tidak seluruhnya diketahui oleh pemegang saham maupun pemberi pinjaman (Scott, 2000). Adverse selection berkaitan dengan etika seorang pengusaha. atau mudharib yang melekat pada dirinya dan tidak dapat diketahui secara pasti oleh shahibul maal. Orang-orang dalam perusahaan biasanya memahami dan mengetahui lebih banyak tentang masalah, informasi dan prospek yang dimiliki perusahaan daripada penyedia dana yang berasal dari pihak luar. Penyimpangan itu dapat berupa kemungkinan terjadinya kecurangan atau penyimpangan terhadap pembagian hasil usaha diantara keduanya atau saling mencoba memanfaatkan pihak lain untuk kepentingan sendiri.

Menurut Sadr dan Iqbal (2000), menyatakan bahwa adverse selection terjadi pada kontrak utang ketika peminjam memiliki kualitas yang tidak baik latas kredit diluar batas ketentuan tingkat keuntungan tertentu, sedangkan moral hazard terjadi ketika melakukan penyimpangan atau menimbulkan resiko yang lebih besar pada kontrak. Untuk itu harus ada proses monitoring dari Bank untuk meminimalisir adanya informasi asimetrik terhadap masalah agency pembiayaan ,mudharabah.

\section{Pengajuan Hipotesis}

Moral hazard dan adverse selection merupakan faktor terpenting dalam mempengaruhi pembiayaan mudharabah. Dalam buku Muhammad (2005) menyebutkan bahwa teknik mudharabah di Bank Syari'ah mengenai keuntungan dan kerugian dapat dihitung secara akurat karena pendapatan dan biaya dapat dipisahkan akan tetapi pembiayaan mudharabah ini syarat akan adanya moral hazard dan preferensi dari mudharib yang biasa disebut adverse selection. Adverse selection dalam kontrak mudharabah ini sering terjadi karena banyak ketidakseimbangan informasi yang diberikan oleh agen kepada pemilik modal 
tentang prospek atas usaha yang sedang digeluti. Atas dasar itu maka hipotesis yang diajukan dalam penelitian ini adalah:

H1: $\quad$ moral hazard berpengaruh positif terhadap masalah agency contractual dalam pembiayaan mudharabah.

$\mathrm{H} 2$ : adverse selection berpengaruh positif terhadap masalah agency contractual dalam pembiayaan mudharabah.

H3: Informasi asimetrik (adverse selection dan moral hazard) secara bersama-sama berpengaruh positif terhadap masalah agency contractual dalam pembiayaan mudharabah.

\section{Metode Penelitian}

Penelitian dilakukan di Bank Umum Syari'ah di wilayah Yogyakarta dan Jawa Tengah yaitu Bank BTN Syariah di Yogyakarta, Bank Mandiri Syariah Demak dan Bank BRI Syariah di Semarang.

\section{Variabel Penelitian}

Dalam penelitian ini ada tiga variabel penting yang akan pembahasan yaitu masalah agency kontraktual sebagai variabel dependent dan informasi asimetrik yang terdiri dari Adverse selection dan Moral hazard sebagai variabel independent.

\section{Data dan Metode Pengumpulan Data}

Data diperoleh dari data primer yang dilakukan dengan cara menyebarkan kuesioner dan diisi oleh manajer atau pihak-pihak bank bersangkutan. Daftar pertanyaan dalam kuesioner ini mencakup tiga variabel yaitu informasi asimetrik (moral hazard dan adverse selection) dan masalah agency kontaktual dalam pembiayaan mudharabah.

\section{1). Data variabel moral hazard meliputi:}

1. Ketepatan dalam melaporkan kondisi keuangan perusahaan/proyek.

2. Akhlak Mudharib.

3. Kesesuaian planning dengan pembiayaan actual.

4. Pengendalian biaya-biaya operasional.

5. Likuiditas.

6. Kelalaian yang dilakukan mudharib.

\section{2). Data variabel Adverse selection meliputi:}

1. Kesesuaian investasi terhadap perkembangan usaha yang dijalankan.

2. Laporan keuangan.

3. Study kelayakan bisnis 
4. Reputasi perusahaan.

5. Prosedur pembiayaan.

6. Pengalaman dan kualifikasi pengusaha.

3). Data variabel agency contractual meliputi

1. Return.

2. Pengambilan keuntungan pribadi.

3. Melakukan overinvestment dan underinvestment.

4. Efesiensi.

5. Ketaatan terhadap kewajiban.

6. Pengendalian persediaan.

\section{Metode Analisis}

Data dianalisis dengan menggunakan dan dirumuskan ke dalam persamaan regresi berganda sebagai berikut :

$$
\mathbf{Y}=\boldsymbol{\beta}_{\mathrm{o}}+\boldsymbol{\beta}_{1} \mathrm{MH}+\boldsymbol{\beta}_{2} \mathrm{ADS}+\overline{\mathbf{e}}
$$

Dimana,

$\mathrm{Y}=$ Agency Contractual Problem

$\beta_{\mathrm{o}} \quad=$ Konstanta yaitu jarak dari titik asal (titik 0 ) ketitik perpotongan antara garis regresi dengan sumbu $Y$

$\beta_{1}, \beta_{2} \quad=$ Koefisien

MH = Moral hazard

ADS = Adverse selection

$\overline{\mathrm{e}} \quad-\quad=$ error random, diasumsikan $\overline{\mathrm{e}}=0$

\section{Uji Hipotesis}

Untuk mengetahui pengaruh variabel bebas dengan variabel terikat maka dilakukan uji secara parsial (uji T) dan uji secara simultan (uji F).

\section{Pembahasan}

\section{Analisis Statistik Deskriptis.}

Untuk mengetahui sifat-sifat (karakteristik) dari sampel yang digunakan dalam penelitian. Dari statistik deskriptif dapat diketahui jumlah, nilai rata-rata sampel dan standar deviasi dari masing-masing variabel.

\section{Analisis Regresi Linear Berganda}

Untuk mengetahui seberapa besar pengaruh variable independen dan terhadap variable dependen. 
Berdasarkan hasil analisis regresi, diperoleh rumusan sebagai berikut:

$$
\mathrm{Y}=0.709069+0.464946 \mathrm{MH}+0.274237 \mathrm{ADS}+\overline{\mathrm{e}}
$$

1. Nilai Konstanta sebesar 0.709069. Apabila tidak ada pengaruh antara variabel moral hazard dan variabel adverse selection, maka masalah agency contractual atau nilai Y sama dengan nilai konstanta yaitu sebesar 0.709069 .

2. Koefisien Moral hazard

Koefisien variabel moral hazard positif menaikkan variabel agency contractual sebesar 0.464946 dengan asumsi bahwa variabel lain tetap berada pada posisi konstan.

3. Koefisien Adverse selection

Koefisien variabel adverse selection positif menaikkan agency contractual sebesar 0.274237 dengan asumsi bahwa variabel lain tetap berada pada posisi konstan.

\section{Uji Asumsi Klasik}

Untuk mengetahui apakah hasil estimasi regresi yang dilakukan bebas dari gejala heteroscedasticity, dan gejala multicollinearity.

1). Uji Multicollinearity

Tabel 2 Correlation Matrix

\begin{tabular}{|c|c|c|}
\hline & MH & ADS \\
\hline MH & 1.000000 & 0.428112 \\
\hline ADS & 0.428112 & 1.000000 \\
\hline
\end{tabular}

Tabel di atas menunjukkan bahwa korelasi variable independen lebih kecil dari 0,8 , ini menunjukkan bahwa data tidak mengandung gejala multikolinieritas. 2). Uji Heteroscedasticity

Bertujuan untuk menguji apakah dalam model regresi terjadi ketidaksamaan varians dan residual satu pengamatan ke pengamatan yang lain. 
Nurfauziah \& Nur Syakdiyyah, Pengaruh Informasi Asimetrik terhadap Masalah..

Tabel 3. Hasil Uji Heteroskedasticity (no cross terms)

White Heteroskedasticity Test:

\begin{tabular}{|lll|l}
\hline F-statistic & 0.406311 & Probability & 0.803319 \\
Obs*R-squared & 1.720423 & Probability & 0.787004 \\
\hline
\end{tabular}

Test Equation:

Dependent Variable: RESID 2

Method: Least Squares

Date: 05/09/11 Time: 15:53

Sample: 161

Included observations: 61

\begin{tabular}{|crlr|r}
\hline \multicolumn{1}{c|}{ Variable } & Coefficient & \multicolumn{1}{c|}{ Std. Error } & t-Statistic & Prob. \\
\hline C & 1.408997 & 1.446361 & 0.974167 & 0.3342 \\
MH & -0.394233 & 0.920384 & -0.428335 & 0.6700 \\
MH^2 & 0.071818 & 0.182880 & 0.392706 & 0.6960 \\
ADS & -0.557146 & 0.809126 & -0.688578 & 0.4939 \\
ADS^2 & 0.102829 & 0.160885 & 0.639143 & 0.5253 \\
\hline R-squared & 0.028204 & Mean dependent var & 0.156440 \\
Adjusted R-squared & -0.041210 & S.D. dependent var & 0.240771 \\
S.E. of regression & 0.245682 & Akaike info criterion & 0.108853 \\
Sum squared resid & 3.380134 & Schwarz criterion & 0.281875 \\
Log likelihood & 1.679988 & F-statistic & 0.406311 \\
Durbin-Watson stat & 1.745530 & Prob(F-statistic) & 0.803319 \\
\hline
\end{tabular}

Dari hasil pengujian diatas, dapat dilihat bahwa nilai probability yaitu sebesar 0.787004 , lebih besar dari $\alpha=5 \%$ artinya bahwa tidak ditemukan gejala heteroskedastisitas atau homoskedastisitas dalam model ini. 


\section{3). Uji Normalitas}

\section{Grafik Uji Normalitas}
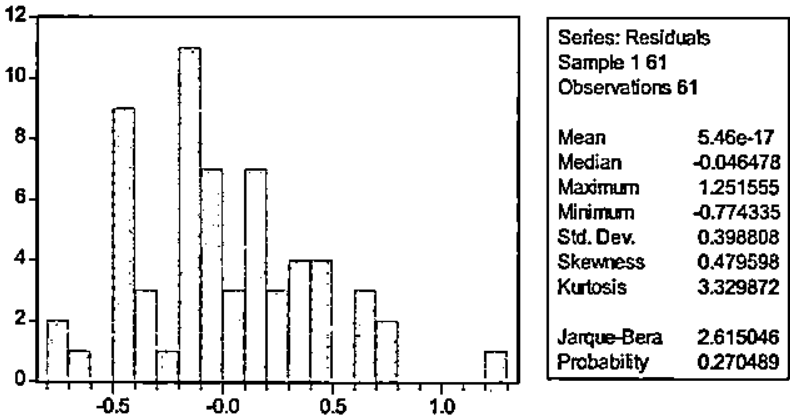

\section{4). Pengujian Hipotesis}

Uji ini untuk mengetahui pengaruh variabel independen terhadap variabel dependen, baik secara parsial maupun secara bersama-sama.

\section{Tabel 4 Hasil Uji Least Squares}

Dependent Variable: $Y$

Method: Least Squares

Date: 05/09/11 Time: 15:49

Sample: 161

Included observations: 61

\begin{tabular}{lclll}
\hline \multicolumn{1}{c}{ Variable } & Coefficient & Std. Error & t-Statistic & Prob. \\
\multicolumn{1}{c}{ C } & 0.709069 & 0.392418 & 1.806923 & 0.0760 \\
MH & 0.464946 & 0.155985 & 2.980701 & 0.0042 \\
ADS & 0.274237 & 0.133383 & 2.056006 & 0.0443 \\
\hline & & & \\
R-squared & 0.279314 & Mean dependent var & 2.549180 \\
Adjusted R-squared & 0.254463 & S.D. dependent var & 0.469776 \\
S.E. of regression & 0.405625 & Akaike info criterion & 1.081156 \\
Sum squared resid & 9.542852 & Schwarz criterion & 1.184970 \\
Log likelihood & -29.97527 & F-statistic & 11.23944 \\
Durbin-Watson stat & 1.408567 & Prob(F-statistic) & 0.000075 \\
\hline
\end{tabular}

1. Pengujian hipotesis pertama

Hasil uji hipotesis pertama yang menyebutkan bahwa menunjukkan variabel moral hazard berpengaruh terhadap masalah agency contractual dalam 
pembiayaan mudharabah terbukti karena t- ${ }_{\text {prob }}\left(\mathrm{p}-{ }_{\text {value }}\right)$ adalah sebesar 0.0042 yang mana nilainya lebih kecil dari $5 \%$.

2. Pengujian hipotesis kedua

Dari hasil pengujian pada tabel 4 variabel adverse selection diketahui t- ${ }_{\text {prob }}$ $\left(\mathrm{p}_{\text {value }}\right.$ ) sebesar 0.0443 lebih kecil dari $5 \%$ ini berarti Ho ditolak dan Ha diterima, yang artinya hipotesis yang menyebutkan bahwa adverse selection berpengaruh terhadap masalah agency contractual dalam pembiayaan mudharabah terbukti.

3. Pengujian hipotesis ketiga

Dalam hasil pengujian yang terdapat pada tabel 4.4 diketahui bahwa $\mathrm{F}_{\text {prob }}$ $(\mathrm{p}-$ value $)$ adalah sebesar 0.000075 lebih kecil dari $5 \%(0.000075<5 \%)$ hal ini mengindikasikan bahwa Ho ditolak dan Ha diterima. Artinya moral hazard dan adverse selection bersama-sama berpengaruh terhadap masalah agency contractual dalam pembiayaan mudharabah.

\section{Penutup}

\section{Simpulan}

Dari hasil analisis dapat ditarik suatu kesimpulan bahwa:

1. Moral hazard berpengaruh secara signifikan terhadap agency contractual. Moral hazard adalah variabel paling potensial yang mempengaruhi masalah agency contractual. Moral hazard merupakan bentuk penyelewengan terhadap moral seorang mudharib misalnya pengelolaan internal bisnis yang tidak dilakukan secara profesional oleh mudharib, ketidaktepatan dalam melaporkan keuangan, mudharib tidak taat dalam menjalankan kesepatan awal, sehingga bisnis yang dibangun tidak berjalan dengan semestinya dan mempengaruhi tingkat pencapaian tujuan pembiayaan

2. Adverse selection berpengaruh terhadap agency contractual. Adverse selection merupakan bentuk penyimpangan terhadap pembagian hasil usaha diantara keduanya atau saling mencoba memanfaatkan pihak lain untuk kepentingan sendiri. Selain itu, ketidakmampuan para pemberi pinjaman untuk meneliti sifat-sifat para peminjam dan segala kemungkinan yang berada disekitar mereka merupakan hal yang dapat memperburuk pencapaian tujuan yang disepakati dalam suatu pembiayaan.

3. Informasi asimetrik yang berupa moral hazard dan adverse selection berpengaruh terhadap agency contractual. Informasi sepihak yang dimiliki oleh mudharib menyebabkan mudharib dapat bertindak diluar kesepakatan tanpa sepengatahuan shahibul maal dan shahibul maal tidak diperkenankan ikut campur dalam bisnis yang sedang dikelola oleh mudharib. 


\section{Saran}

Atas dasar hasil penelitian di atas, maka diharapkan :

1. Untuk meminimalisir adanya informasi asimetrik berupa moral hazard dan adverse selection, bank harus lebih memperhatikan kemampuan staffnya melalui pelatihan dan pengembangan kinerja karyawan.

2. Bank Syari'ah harus dapat meyakinkan pada masyarakat bahwa Bank Syari'ah berbeda dengan Bank Konvensional yang menggunakan sistem bunga yang diharamkan oleh agama, serta mensosialisasikan secara terbuka mengenai pembiayaan yang ada di Bank Syari'ah dan cara pembagian keuntungan yang belum dimengerti oleh masyarakat awam.

3. Diharapkan penelitian selanjutnya untuk lebih memperbanyak sampel bank agar tingkat representatifitas sampel terhadap populasinya semakin tinggi. 


\section{DAFTAR PUSTAKA}

Alqaoud, Latifa M. dan Mervyn K.Lewis.(2001). Perbankan Syari'ah (prinsip, praktik, dan prospek). SERAMBI:Jakarta.

Ántonio, Muhammad syafi'i. (2001). Bank Syari'ah (dari teori ke praktik). Gema Insani:Jakarta.

Arifin, Zainal. (2007). Realisasi Akad Mudharabah dalam Rangka Penyaaluran Dana Dengan Prinsip Bagi Hasil Di Bank Muamalat Indonesia Cabang Semarang. Program Study Magister Kenotariatan. (Dipublikasikan). Program Pasca Sarjana Universitas Diponegoro:Semarang.

Muhammad.(2003). Konstruksi Mudharabah dalam Bisnis Syariah. Pusat Studi Ekonomi Islam STIS. Yogyakarta.

Muhammad. (2003). Kontruksi Mudharabah dalam Pembiayaan Mudharabah pada Bank Syari'ah di Indonesia. Disertai Doktor Ilmu| Ekonomi (Dipublikasikan), Yogyakarta:Program Doktor UII.

Muhammad. (2005). Manajemen Bank Syari'ah. Edisi Revisi.UPP AMPYKPN: Yogyakarta.

Muhammad. (2006). Permasalahan Agensi dalam Pembiayaan Mudharabah pada Bank Syari'ah di Indonesia. Disertai Doktor Ilmu Ekonomi. Yogyakarta:Program Doktor UII.

Sadr, Kazem and Zamir Iqbal. "Choice of Debt or Equity Contract and Asymetrical Information: An Empirical Evidence," Conference Papers, Fourth International Conference on Islamic Economics and Banking Loughborough University, UK, August 13-15, 2000, pp. 487-499.

Scott, William R. (2000). Financial Accounting Theory. Second edition. Canada: Prentice Hall. 